express article10.1096/fj.04-1767fje. Published online November 8, 2004.

\title{
Establishing the background level of base oxidation in human lymphocyte DNA: results of an interlaboratory validation study
}

ESCODD (European Standards Committee on Oxidative DNA Damage), ${ }^{*}$ Catherine M. Gedik, ${ }^{\dagger}$ and Andrew Collins

$\dagger$

Rowett Research Institute, Aberdeen AB21 9SB, UK; Department of Nutrition, University of Oslo, 0316 Oslo, Norway

Corresponding author: Andrew Collins, Department of Nutrition, University of Oslo, P.O. box 1046 Blindern, 0316 Oslo, Norway. E-mail: a.r.collins@medisin.uio.no

* Members of ESCODD in addition to those named individually as authors: Jacques Dubois, Pierre Duez, Léonard Kouegnigan (Université Libre de Bruxelles, Institut de Pharmacie, Belgium); JeanFrançois Rees (Université Catholique de Louvain, Louvain-La-Neuve, Belgium); Steffen Loft, Peter

Møller, Annie Jensen (University of Copenhagen, Denmark); Henrik Poulsen, Bente Riis, Allan Weimann (Rigshospitalet, Copenhagen University Hospital, Denmark); Jean Cadet, Thierry Douki, Jean-Luc Ravanat, Sylvie Sauvaigo (DSM-CEA/Grenoble, France); Henri Faure (University Hospital, Grenoble, France); Isabelle Morel (Université de Rennes 1, France); Bénédicte Morin (University Bordeaux 1, France); Bernd Epe, Inge Eckert (Johannes Gutenberg-Universität, Mainz, Germany); Andrea Hartwig, Tanja Schwerdtle (Universität Karlsruhe, Germany); Piero Dolara, Lisa Giovannelli, Maura Lodovici, Francesco Guglielmi (University of Florence, Italy); Ryszard Olinski, Karol Bialkowski, Marek Foksinski, Daniel Gackowski (The Ludwik Rydygier Medical University in Bydgoszcz, Poland); Zdena Duračková, Jana Muchová, Peter Korytar, Monika Sivonová (Medical Faculty of Comenius University, Bratislava, Slovak Republic); Mária Dušinská, Csilla Mislanová, Helena Petrovská, Božena Smolková (Institute of Preventive and Clinical Medicine, Bratislava, Slovak Republic); José Viña, Ana Lloret, Guillermo Sáez (Universitat de Valencia, Spain); Lennart Möller, Tim Hofer, Hanna Eriksson (Karolinska Institute, Stockholm, Sweden); Eric Gremaud (Centre de Recherche Nestlé, Lausanne, Switzerland); Karl Herbert (University of Leicester, UK); Chris Wild (University of Leeds, UK); Frank Kelly, Christina Dunster (King's College London, UK); Ann White, Sharon Wood, Nicholas Vaughan (Rowett Research Institute, Aberdeen, UK; coordinating laboratory). 


\section{ABSTRACT}

Accurate measurement of low levels of 8-oxo-7,8-dihydro-2'-deoxyguanosine (8-oxodGuo) in DNA is hampered by the ease with which guanine is oxidized during preparation of DNA for analysis. ESCODD, a consortium of mainly European laboratories, has attempted to minimize this artifact and to provide standard, reliable protocols for sample preparation and analysis. ESCODD has now analyzed 8-oxodGuo in the DNA of lymphocytes isolated from venous blood from healthy young male volunteers in several European countries. Two approaches were used. Analysis of 8-oxodGuo by HPLC with electrochemical detection was performed on lymphocytes from 10 groups of volunteers, in eight countries. The alternative enzymic approach was based on digestion of DNA with formamidopyrimidine DNA glycosylase (FPG) to convert 8-oxo-7,8-dihydroguanine (8oxoGua) to apurinic sites, subsequently measured as DNA breaks using the comet assay (7 groups of volunteers, in six countries). The median concentration of 8-oxodGuo in lymphocyte DNA, calculated from the mean values of each group of subjects as determined by HPLC, was 4.24 per $10^{6}$ guanines. The median concentration of FPG-sensitive sites, measured with the comet assay, was 0.34 per $10^{6}$ guanines. Identical samples of HeLa cells were supplied to all participants as a reference standard. The median values for 8-oxodGuo in HeLa cells were 2.78 per $10^{6}$ guanines (by HPLC) and 0.50 per $10^{6}$ guanines (by enzymic methods). The discrepancy between chromatographic and FPG-based approaches may reflect overestimation by HPLC (if spurious oxidation is still not completely controlled) or underestimation by the enzymic method. Meanwhile, it is clear that the true background level of base oxidation in DNA is orders of magnitude lower than has often been claimed in the past.

Key words: DNA oxidation $\bullet$ 8-oxodGuo $\bullet \mathrm{HPLC} \bullet$ comet assay $\bullet$ FPG 
xidative damage within the body arises through the attack of highly reactive forms of oxygen, released during normal respiration and also as part of the inflammatory response.

This kind of damage to various biomolecules, such as lipids, proteins, and DNA, has been implicated in many chronic and degenerative human diseases, as well as in aging. In particular, oxidative DNA damage may be one of the causes of cancer. It is therefore especially important that we should be able to measure this damage reliably. The most commonly used biomarker of DNA oxidation, in epidemiological as well as experimental studies, is 8-oxo-7,8-dihydro-2'deoxyguanosine (8-oxodGuo). Yet, estimates of the concentration of 8-oxodGuo in DNA from normal human cells vary by as much as 1000 -fold, depending largely on which procedure is used to measure it (1).

The European Standards Committee on Oxidative DNA Damage (ESCODD) was set up in 1997 to attempt to identify the problems; to devise standard, reliable techniques; and to reach a consensus on the true background level of damage in normal human cells. ESCODD gained funding from the European Commission in 1999 and has operated since February 2000 as a Concerted Action with 25 member laboratories in Europe and one in Japan. Previous reports (2-5) have described the analysis in participating laboratories of solutions of 8-oxodGuo, oligonucleotides with defined amounts of 8oxoGua, calf thymus DNA, calf thymus DNA with experimentally induced 8-oxoGua, pig liver DNA, HeLa cells, and HeLa cells with experimentally induced 8-oxoGua. In this latest round, aimed at validating methods for use in human population studies, laboratories recruited volunteers in their respective countries to provide lymphocytes for analysis of DNA damage, and identical samples of HeLa cells were provided to each laboratory to act as a reference standard.

A variety of methods were used. The chromatographic approach was represented by HPLC with electrochemical detection (HPLC-ECD), both amperometric and coulometric, and HPLC with tandem mass spectrometry (HPLC-MS/MS). A set of methods described as "enzymic methods" make use of the bacterial DNA repair enzyme formamidopyrimidine DNA glycosylase (FPG) to convert 8oxoGuas to apurinic sites and then, via its associated lyase activity, to DNA breaks; these are measured using the comet assay (single cell gel electrophoresis), alkaline unwinding, or alkaline elution. In recent rounds of ESCODD, the enzymic approach has generally given estimates of 8oxoGua that are several times lower (comparing median results from different laboratories) than those obtained using chromatography, and fall within a narrower range. There is convincing evidence that substantial oxidation of guanine occurs during preparation of samples for HPLC analysis, and in ESCODD, we have designed protocols for DNA extraction and hydrolysis specifically to minimize this effect. In contrast to the protracted and vigorous procedures that take place before chromatographic analysis, the enzymic methods involve minimal processing of the sample (e.g., in the comet assay, cells are simply centrifuged, embedded in agarose, incubated with FPG, then with alkali, and electrophoresed); samples are therefore less likely to suffer from spurious oxidation. The present trial was set up to test our success in controlling the artifact, to compare the merits of the two approaches, and to obtain a realistic estimate of background DNA oxidation in normal human cells. 


\section{MATERIALS AND METHODS}

\section{Human lymphocytes: selection of subjects and collection of samples}

The aim of the study was to recruit groups of up to 20 healthy male nonsmokers, aged 20-30 years, in different countries. Eleven partner laboratories took part. Local ethical approval was obtained by each participant.

Five CPT vacutainers containing sodium heparin anticoagulant (Becton-Dickinson, Franklin Lakes, $\mathrm{NJ})$ were used to collect blood (40 $\mathrm{ml}$ in total) from each volunteer by venepuncture on a single occasion. Blood samples were coded, and lymphocytes were obtained by centrifugation within $2 \mathrm{~h}$. They were washed in Roswell Park Memorial Institute (RPMI) medium, centrifuged, resuspended in $1 \mathrm{ml}$ of ice-cold freezing medium (90\% heat-inactivated fetal calf serum, 10\% DMSO), and diluted with freezing medium to a density of $6 \times 10^{6}$ cells $/ \mathrm{ml}$. Two $200 \mu \mathrm{l}$ aliquots in cryovials were chilled slowly (in boxes of expanded polystyrene) to $-80^{\circ} \mathrm{C}$ for the comet assay (if needed) and stored at this temperature. The remainder, for DNA extraction and HPLC analysis, was divided into $\sim 3 \mathrm{ml}$ aliquots in $15 \mathrm{ml}$ tubes, packed upright, and slowly chilled to $-80^{\circ} \mathrm{C}$ as above.

\section{Preparation of HeLa cells as reference standard}

HeLa (human transformed epithelial) cells were prepared by the coordinating laboratory. They were grown to confluence in 36 50-ml flasks (Nalge Nunclon International, Roskilde, Denmark), in Glasgow-modified Eagle's minimal essential medium (GMEM) with 5\% fetal calf serum, 5\% calf serum, supplemented with glutamine and nonessential amino acids. The cells were harvested using trypsin/EDTA, and the cells from each flask were transferred to a polystyrene roller bottle $\left(850 \mathrm{~cm}^{2}\right.$ surface area; Corning Inc., Corning, NY) in 80-100 $\mathrm{ml}$ medium in an $\sim 6 \% \mathrm{CO}_{2}$ atmosphere. The bottles were placed on a roller at $37^{\circ} \mathrm{C}$, and after 7 days, the medium was changed. After a further 4 days, $30 \mathrm{ml}$ medium was added to each bottle, and the next day the cells were harvested from two bottles at a time using trypsin/EDTA. Medium with serum was added to inactivate the trypsin, and the cells were transferred to sterile glass bottles and stored in a $37^{\circ} \mathrm{C}$ incubator until all had been harvested. Cell suspensions were combined and gently inverted to mix, total volume was noted, and cell density was determined using a haemocytometer. Cells were then collected by centrifuging at 700 $\times \mathrm{g}$ for $7 \mathrm{~min}$ at $20^{\circ} \mathrm{C}$. The cell pellet was resuspended in $1 \mathrm{ml}$ freezing medium (GMEM containing $20 \%$ fetal calf serum, with $10 \%$ DMSO). Additional freezing medium was added to bring the density to $5 \times 10^{6}$ cells $/ \mathrm{ml}$, and the cell suspension was divided into aliquots of the following: 1) $30 \times 10^{6}$ cells $(6 \mathrm{ml})$ for chromatographic methods; 2$) 1.5 \times 10^{6}$ cells $(0.3 \mathrm{ml})$ for the comet assay; 3$) 6 \times 10^{6}$ cells $(1.2 \mathrm{ml})$ for alkaline unwinding; and 4) $10 \times 10^{6}$ cells $(2 \mathrm{ml})$ cells for alkaline elution.

The cells were chilled slowly in expanded polystyrene boxes to $-80^{\circ} \mathrm{C}$. Aliquots were sent to participating laboratories on dry ice, and all arrived frozen. They were then stored at $-80^{\circ} \mathrm{C}$. Samples retained for use by the coordinating laboratory were kept on dry ice for $24 \mathrm{~h}$ to mimic conditions of postage and then stored at $-80^{\circ} \mathrm{C}$ until use.

HeLa cells were sent to 17 laboratories for HPLC analysis with electrochemical detection (HPLCECD) and to two laboratories for HPLC-MS/MS analysis. Each participant received three aliquots for the ESCODD standard DNA extraction/hydrolysis method (see below) and a further three 
for the participant's own method (if it differed from the standard method). Additional tubes for practising the standard method were provided on request. Participants were requested 1) to use as many cells as required for one DNA extraction from each tube, 2) to extract the DNA from each tube on different occasions if possible, and 3) to make triplicate injections of each sample.

Eight laboratories carrying out the comet assay were sent three aliquots of HeLa cells for analysis by the participant's own method on different days; each sample was to be analyzed in triplicate. Participants whose comet assay method differed significantly from the ESCODD protocol were sent an extra set of cells so that both methods could be used.

Three samples of HeLa cells were sent to two laboratories using alkaline unwinding, and to one laboratory using alkaline elution, to be analyzed on three separate occasions in triplicate.

\section{DNA extraction and hydrolysis for HPLC analysis}

A recommended procedure for extraction and hydrolysis of DNA was devised on the basis of comparative tests of different methods carried out by members of ESCODD (6). Frozen aliquots of HeLa and lymphocyte suspensions were thawed in a $37^{\circ} \mathrm{C}$ water bath with gentle agitation. As soon as they were thawed (lymphocyte aliquots from one volunteer being combined in a single $50 \mathrm{ml}$ centrifuge tube), the cell suspensions were made up to $45 \mathrm{ml}$ with ice-cold PBS (phosphate-buffered saline; $0.14 \mathrm{M} \mathrm{NaCl}, 3 \mathrm{mM} \mathrm{KCl}, 8 \mathrm{mM} \mathrm{Na} 2 \mathrm{HPO} 4,1 \mathrm{mM} \mathrm{KH} 2 \mathrm{PO} 4, \mathrm{pH} 7.4)$ and centrifuged at 700

$\times \mathrm{g}$ for $7 \mathrm{~min}$ at $4^{\circ} \mathrm{C}$. The supernatant was discarded and the cell pellet dispersed in $1 \mathrm{ml}$ of PBS, diluted to $45 \mathrm{ml}$ with PBS, and recentrifuged. The pellet was dispersed in $1.5 \mathrm{ml}$ of ice-cold buffer A (10 mM Tris, $0.32 \mathrm{M}$ sucrose, $5 \mathrm{mM} \mathrm{MgCl}_{2}, 0.1 \mathrm{mM}$ deferoxamine mesylate; adjusted to $\mathrm{pH} 7.5$; then $1 \%$ Triton X-100 added, and buffer made up to final volume) and transferred to a $2 \mathrm{ml}$ Eppendorf tube. The nuclei from the lysed cells were pelleted by centrifugation at $1500 \times \mathrm{g}$ for $5 \mathrm{~min}$ at $4^{\circ} \mathrm{C}$. The supernatant was removed and $1.5 \mathrm{ml}$ buffer A added to the pellet, which was vortex-mixed for $10 \mathrm{~s}$ and then centrifuged again at $1500 \times \mathrm{g}$ for $5 \mathrm{~min}$ at $4^{\circ} \mathrm{C}$.

The supernatant was discarded, and $0.6 \mathrm{ml}$ of buffer B (10 mM Tris, $5 \mathrm{mM} \mathrm{Na} 2 \mathrm{EDTA}, 0.15 \mathrm{mM}$ deferoxamine mesylate, $\mathrm{pH}$ 8.0) was added to the pellet. The pellet was dispersed by vortexing, $35 \mu \mathrm{l}$ of $10 \%$ SDS added, and vortexing repeated. Three $\mu 1$ of RNase IIIA (Sigma, Poole, UK; $100 \mathrm{mg} / \mathrm{ml}$ ) and $8 \mu \mathrm{l}$ of RNase T1 (Sigma; $1 \mathrm{U} / \mu \mathrm{l}$ ), both in $10 \mathrm{mM}$ Tris, $\mathrm{pH} 8.0$, were added, and the mixture gently vortexed for $10 \mathrm{~s}$. After incubation for $15 \mathrm{~min}$ at $50^{\circ} \mathrm{C}$, and cooling to $37^{\circ} \mathrm{C}, 30 \mu \mathrm{l}$ of protease (Qiagen; dissolved at $20 \mathrm{mg} / \mathrm{ml}$ in water) was added, and the mixture was gently vortexed for $10 \mathrm{~s}$ and incubated at $37^{\circ} \mathrm{C}$ for $1 \mathrm{~h}$.

The mixture was cooled to $4^{\circ} \mathrm{C}$ and transferred to a $15 \mathrm{ml}$ centrifuge tube with $1.2 \mathrm{ml}$ of cold NaI solution (40 mM Tris, $20 \mathrm{mM} \mathrm{Na} 2 \mathrm{EDTA}$, 7.6 M NaI puriss. grade [Fluka, St Gallen, Switzerland], $0.3 \mathrm{mM}$ deferoxamine mesylate, $\mathrm{pH} 8.0$ ), and vortexed vigorously for $30 \mathrm{~s}$. Two $\mathrm{ml}$ of 2-propanol was added, and the tube was gently inverted several times to mix before centrifuging at $5000 \times \mathrm{g}$ for 5 min at $20^{\circ} \mathrm{C}$. The supernatant was aspirated off, the pellet was washed with $40 \%$ 2-propanol and centrifuged at $5000 \times \mathrm{g}$ for $5 \mathrm{~min}$ at $20^{\circ} \mathrm{C}$, and the pellet was then washed with $70 \%$ ethanol $\left(-20^{\circ} \mathrm{C}\right)$ and centrifugation was repeated at $5000 \times \mathrm{g}$ for $5 \mathrm{~min}$ but at $4^{\circ} \mathrm{C}$. The ethanol was removed with a 
pipette, and the DNA was left to dry in the tube for $5 \mathrm{~min}$. The DNA was suspended in $0.1 \mathrm{mM}$ deferoxamine mesylate, immediately frozen, and stored at $-80^{\circ} \mathrm{C}$.

For hydrolysis, the DNA in deferoxamine mesylate was thawed, and to it was added $10 \mu \mathrm{l}$ of nuclease P1 (Sigma) dissolved in $0.3 \mathrm{M}$ sodium acetate, $1 \mathrm{mM} \mathrm{ZnSO}_{4}, \mathrm{pH} 5.3$, at a concentration of $1 \mathrm{U} / \mu 1$. The mixture (with still undissolved DNA) was vortex-mixed and incubated at $37^{\circ} \mathrm{C}$ for $2 \mathrm{~h}$, vortexing again after $1 \mathrm{~h}$ of incubation. Then $0.2 \mu \mathrm{l}$ of alkaline phosphatase at $20 \mathrm{U} / \mu \mathrm{l}$ (Roche Diagnostics Ltd., Lewes, UK) and $10 \mu \mathrm{l}$ of $0.5 \mathrm{M}$ Tris, $1 \mathrm{mM} \mathrm{Na} 2$ EDTA, $\mathrm{pH}$ 8.0, were added, the mixture was vortexmixed and incubated for $1 \mathrm{~h}$ at $37^{\circ} \mathrm{C}$, and vortexed again after $30 \mathrm{~min}$. The mixture was centrifuged for $5 \mathrm{~min}$ at $5000 \times \mathrm{g}$, and aliquots of the supernatant were taken for analysis.

Most partners used their own procedures alongside the standard ESCODD procedure. Details of variations from the standard protocol are given in Table 1 and Table 2.

\section{Analysis of 8-oxodGuo by chromatography}

HPLC-ECD: Separation of DNA hydrolysate, 8-oxodGuo, and dGuo samples on a C18 column (varying in dimensions and manufacturer) was followed by electrochemical detection (coulometric or, in two laboratories, amperometric) of 8-oxodGuo, and UV detection of dGuo. Results that were below the limit of detection are recorded as zero. (It is not possible to give such results an assumed value of, say, half the limit of detection; the limit of detection is an absolute amount or concentration, but our results are expressed relative to the amount of dGuo in the sample, which can vary.)

HPLC-MS/MS: Two laboratories used liquid chromatography with online detection by MS. (Only one was able to return results.) Nucleosides were separated on a C18 column and injected into a triple quadrupole mass spectrometer for identification and quantitation of products using heavy isotopelabeled internal standards (necessary to control for variation in ionization before MS).

\section{Analysis of FPG-sentitive sites}

Comet assay: Cells were thawed by gentle agitation in a $37^{\circ} \mathrm{C}$ water bath and immediately centrifuged at $200 \times \mathrm{g}$ for $3 \mathrm{~min}$ at $4^{\circ} \mathrm{C}$. Pelleted cells were dispersed in $0.4 \mathrm{ml}$ of cold RPMI medium with $10 \%$ heat-inactivated fetal calf serum, and $30 \mu \mathrm{l}$ aliquots were added to $1 \mathrm{ml}$ of cold PBS. The cells were centrifuged again, dispersed in $85 \mu \mathrm{l}$ of low-melting-point agarose at $37^{\circ} \mathrm{C}$, and placed on a microscope slide. Lysis with Triton X-100 and 2.5 M NaCl leaves "nucleoids" (containing supercoiled DNA) embedded in the agarose. Alkaline incubation and electrophoresis follows, as described in detail previously (7). Essentially, the comet assay measures DNA breaks by their ability to relax DNA supercoiling; the relaxed DNA loops extend under electrophoresis to form a comet-like image when viewed under fluorescence microscopy. The percentage of DNA in the comet tail indicates the frequency of breaks. Calibration is indirect, based on a standard curve constructed using ionizing radiation to induce DNA breaks at known frequency ( 0.31 breaks per $10^{9}$ daltons per Gray).

Laboratory 4 performed the comet assay by the standard method, in which alkaline denaturation and electrophoresis are carried out at an ambient temperature of $4^{\circ} \mathrm{C}$, and also by their own method in which denaturation and electrophoresis are at $18^{\circ} \mathrm{C}$. For both methods, they used their own washing

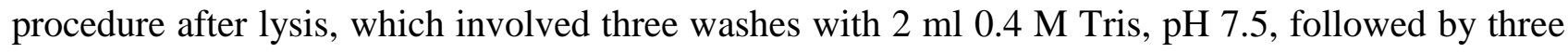


washes with $2 \mathrm{ml}$ of enzyme buffer, instead of the more usual method of immersing the slides in 100 $\mathrm{ml}$ enzyme buffer for three washes of 5 min. Laboratory 3 used the standard method but with a 45 min incubation (instead of $30 \mathrm{~min}$ ) with FPG.

Alkaline elution: Cells were thawed and dispersed in $5 \mathrm{ml} \mathrm{PBS}$ at $0^{\circ} \mathrm{C}$. Aliquots containing $10^{6}$ cells were loaded on polycarbonate membrane filters ( $25 \mathrm{~mm}$ diameter, $2 \mu \mathrm{m}$ pore size) and analyzed for single-strand breaks and FPG-sensitive modifications as described previously $(8,9)$. Briefly, the rate at which single-stranded DNA moves through the filter depends on the size of the fragments. Again, calibration is by comparison with irradiated DNA.

Alkaline unwinding: Frozen aliquots of cell suspensions were thawed by gently shaking in a $37^{\circ} \mathrm{C}$ water bath. Immediately after thawing, they were transferred into a centrifuge tube and cell suspensions were diluted to $15 \mathrm{ml}$ with cold RPMI medium containing $10 \%$ fetal calf serum. After centrifugation at $200 \times \mathrm{g}$ for $5 \mathrm{~min}$ at $4^{\circ} \mathrm{C}$, cells were washed with cold PBS, counted, and centrifuged again. Samples were incubated with FPG, and then cells were subjected to alkaline treatment for a fixed period. The rate of unwinding in alkali is increased if the DNA contains breaks, and the break frequency is calculated from the fractions of single- and double-stranded DNA as measured by hydroxyapatite chromatography, calibrating with ionizing radiation. Full details are in refs 10 and 11.

FPG was prepared from Escherichia coli containing an overproducing vector. Laboratories 3 and 10 obtained the enzyme from Serge Boiteux (CNRS-CEA/Fontenay aux Roses, France); other laboratories used extracts prepared in the Rowett Research Institute or at the Institute of Pharmacy, University of Mainz.

\section{RESULTS}

\section{HeLa cells, chromatographic methods}

Fourteen laboratories submitted results obtained with HPLC-ECD. Twelve used coulometric detection (laboratories 2, 3, 5, 6, 13, 14, 15, 16, 21, 23, 25, and 28), and two used amperometric detection (laboratories 4 and 9). Laboratory 3 also submitted results for HPLC-MS/MS. Participants 3, 4, and 23 used the ESCODD method only.

Figure 1 shows the concentrations of 8-oxodGuo found in HeLa cells by chromatographic methods (both laboratories' own methods, and the standard procedure recommended by ESCODD). The overall mean values were 3.38 and 2.628 -oxodGuo per $10^{6} \mathrm{dGuo}$ for own and ESCODD procedures, respectively (not significantly different); overall median values were 2.78 and 2.73 8oxodGuo per $10^{6}$ dGuo, respectively.

\section{HeLa cells, enzymic methods}

Eight laboratories submitted results for the comet assay (1, 2, 3, 4, 5, 6, 14, and 15). Participant 8 submitted results for alkaline elution, and participants 10 and 23 submitted results for alkaline unwinding. Results are shown in Figure 2. The median value from all enzymic methods is 0.50 FPGsensitive sites $/ 10^{6}$ guanines in HeLa cell DNA, and the results show a 10-fold variation overall, from 
0.14 to 1.47 FPG-sensitive sites $/ 10^{6}$ guanines. Laboratory 23 was using the alkaline unwinding technique for the first time, which may account for the high variability in the results.

\section{8-oxodGuo levels in human lymphocyte DNA}

Eleven laboratories recruited volunteers $(1,2,4,5,6,13,14,15,16,21$, and 28), although Participant 13 had only three subjects. Laboratory 1 carried out only the comet assay. and laboratories 13, 16, 21. and 28 carried out only HPLC-ECD. Laboratories 2, 4, 5, 6, 14. and 15 reported results for both HPLC-ECD and the comet assay. The results are displayed as mean values from each laboratory in Figure 3 (HPLC-ECD) and Figure 4 (comet assay). The "mean of means" (i.e., the mean of all individual laboratory means) for HPLC is 3.73 8-oxodGuo per $10^{6} \mathrm{dGuo}$, whereas the median value is 4.24. With the comet assay, the mean of means and the median are both 0.34 FPG-sites per $10^{6}$ guanines. Thus, the chromatographic and enzymic approaches give estimates of background 8oxodGuo in lymphocytes that differ by factors of 11-12. Looking only at those laboratories that used both HPLC and the comet assay, the overall mean (and median) values of 8oxodGuo are 4.40 and 0.36 per $10^{6}$ guanines, respectively - again, differing by a factor of $\sim 12$. The differences between laboratories may reflect national patterns, but there are too few results from different laboratories in the same country to be sure that the variations are reliable. There is no significant correlation between the mean values obtained by the two methods, compared across laboratories.

The CVs for HPLC determinations of HeLa (inter- and intratube) and lymphocytes (intrasubject) are shown in Table 3.

\section{DISCUSSION}

Our aims in this interlaboratory investigation were 1) to compare the performance of various assays in measuring background levels of 8-oxoGua or 8-oxodGuo, using standard samples of HeLa cells; 2) to establish the range of 8-oxoGua/8-oxodGuo levels to be expected in normal human lymphocyte DNA; and 3) to look for differences in mean background levels of 8-oxoGua/8oxodGuo in lymphocytes collected from healthy male volunteers in different countries.

\section{Chromatographic determination of 8-oxodGuo}

In a previous ESCODD trial, we examined the ability of the various assay methods to detect a doseresponse, using HeLa cells treated with the photosensitizer Ro 19-8022 and visible light to induce different amounts of 8-oxoGua. We concluded that HPLC-ECD was very accurate when measuring this experimentally induced base oxidation ( 7 of 8 laboratories found essentially the same slopes of dose-response curves). However, there was no agreement over the background level of 8-oxodGuo; estimates varied between 0.36 and 328 -oxodGuo per $10^{6} \mathrm{dGuo}(5)$. This we attributed to the unsolved problem of adventitious oxidation of guanine during sample preparation.

Whether further improvement in technique (including adoption of a standard protocol for sample preparation) has improved the situation can be judged from the results reported here with standard samples of (untreated) HeLa cells. Excluding all results that are "not detected," there is a 32-fold variation in the mean values for 8-oxodGuo in HeLa DNA measured by HPLC when using own methods of DNA extraction and hydrolysis, and a 13-fold variation when using the ESCODD method. The latter represents a considerable improvement on the results from previous ESCODD trials. 
However, the fact that variations still occur, even when the standard ESCODD protocol is in use, indicates that all the sources of variation or of spurious oxidation have still not been identified and controlled. It is seen from Fig. $1 A$ that about half of the laboratories report values of $\sim 4-5$ 8oxodGuo per $10^{6} \mathrm{dGuo}$, and it is tempting to assume that the few very low figures must be the result of some experimental anomaly. But equally it is possible that these represent laboratories that have managed to minimize the spurious oxidation. Clearly, whatever the case, to account for the discrepant results there must be some divergence of experimental conditions between laboratories, in steps not covered by the standard protocol, that is, in the earliest stages of preparation, or during HPLC itself. In future, the use of immunoaffinity chromatography to preconcentrate 8-oxodGuo and so discard the excess of unmodified dGuo before HPLC (12) might limit adventitious oxidation occurring during HPLC.

Eight laboratories submitted results with HPLC using both their own, and the ESCODD methods. The degree of agreement between the methods can be assessed using a Bland and Altman plot of difference between values by the two methods against mean of the two values (13), as shown in Figure 5. Six laboratories showed reasonable agreement between the two methods. Two laboratories-those reporting the highest values with their own method - did not agree well.

Participant 15's own method stands out in three respects. First, it produces a mean value about half that obtained in the same laboratory using the ESCODD method (though the difference is not statistically significant). Second, it gives the lowest values of all returned (excluding laboratories that reported no detectable peaks). Third, the method involves radical departures from the standard procedure, viz. the omission of RNase and proteinase treatments, keeping all solutions on ice (or colder) throughout, the use of TEMPO and guanidine thiocyanate (GTC), and dissolving the DNA precipitate in water containing catalase (and TEMPO) at the hydrolysis step. However, in a previous direct comparison of methods (6), the GTC-based method did not produce the lowest value for 8 oxodGuo concentration, and so the value of these additional precautions is questionable.

\section{Enzymic determination of 8-oxoGua}

The alternative approach to chromatography is the use of enzymic conversion of 8-oxoGua to DNA breaks, which are then assayed by a variety of methods. Generally, in comparison with chromatographic methods, this approach has given lower estimates of background damage $(1,5,14)$. One possible explanation, of course, is that the methods using FPG, in general, underestimate 8oxoGua by several-fold, because of a failure of the enzyme FPG to detect all lesions, or because lesions occur in clusters so close together that they are detected as a single break (although this may occur only rarely). On the other hand, since FPG detects other oxidized purines in addition to 8oxoGua, our estimates of 8-oxoGua may be too high. It is also possible that the calibration of these assays, using ionizing radiation to induce known frequencies of breaks, is inaccurate. However, doseresponse experiments conducted with both alkaline elution (15) and the comet assay (14) in comparison with HPLC indicate that enzymic methods and HPLC measure experimentally induced 8-oxoGua (in cultured cells) with very similar efficiency (i.e., similar dose-response slopes), and that the main problem is therefore spurious oxidation inflating HPLC measurements.

The range of estimates of background 8-oxoGua in HeLa cells using the comet assay (Fig. 2) is 10fold. The overall range reflects extremes, and as is the case also with HPLC, most individual results agree much more closely than this range suggests. 
The reason for distributing HeLa cells in this trial was to provide a reference standard, so that results for lymphocytes could be normalized, eliminating minor interlaboratory variations. However, because the values reported for HeLa cells (measured by chromatographic or enzymic method) showed large variations, it was considered that any attempt at normalization would simply add further variation to the results, rather than controlling for it.

\section{8-oxodGuo (8-oxoGua) levels in human lymphocyte DNA}

All laboratories applied their own DNA extraction method to the lymphocytes. In addition, laboratory 21 measured the same samples of lymphocyte DNA using their preferred method for DNA isolation and hydrolysis, alongside the standard ESCODD method. There was no significant correlation $(r=-$ 0.26) between the results for the two methods. The individual values obtained using the ESCODD protocol showed little variation. Results with the laboratory's own method were on average 1.67 times higher, and interindividual variation was more marked. With HeLa cells, in contrast, this laboratory found very similar 8-oxodGuo levels for the two methods.

Six laboratories measured both 8-oxodGuo and FPG sites on the same samples of lymphocytes. If levels of oxidized bases in DNA really do vary between subjects, we should expect individual values of 8-oxodGuo (by HPLC) and FPG-sensitive sites (by comet assay) to show a significant, positive correlation. (This is to assume that FPG-sites are predominantly 8-oxoGua, or at least that 8-oxoGua occurs as a fixed proportion of the total FPG-sensitive sites.) There are several possibilities. If the chromatographic and enzymic methods are measuring the lesion with equal efficiency and accuracy, there should be a numerical correspondence in the values. Clearly, because the overall mean values, comparing HPLC and enzymic lymphocyte determinations, differ by a factor of 12, this is not the case. But there could still be a correlation between the paired values, without numerical correspondence. One laboratory (participant 6) found such a correlation, significant at $P<0.001$ (Table 4). This correlation does not, of course, indicate agreement, and in fact, HPLC values from this partner were again consistently higher than comet assay estimates, by a factor of 12 . The other laboratories showed no significant correlation between the results with the two methods.

When the pairs of values from all six laboratories that measured 8-oxodGuo and FPG-sensitive sites are analyzed together, there is a significant but weak positive correlation. It is, however, more instructive to compare the two approaches after z-transforming the results to allow for the fact that values with HPLC are several times higher than values obtained using the enzymic approach. Figure $\underline{6}$ is a Bland and Altman plot of the difference between individual values against the mean of individual values, following z-transformation. Only one laboratory (participant 6) had results that are close to the line of agreement between the two methods.

\section{Conclusions}

We are left with a series of questions, rather than the answers we had hoped for. Is spurious oxidation under control? Apparently not, to judge by the very variable results obtained with identical samples of HeLa cells. If we could eliminate this artifact, would HPLC-ECD be sensitive enough to measure the low levels in real biological samples? Apart from the problem of accurate measurement of small peaks, there is the challenge of identifying 8-oxodGuo unequivocally. Normally a voltammogram can give a tentative identification, but there is insufficient DNA in the lymphocytes from blood samples 
to do this. Thus, the only way to identify the 8-oxodGuo peak is by its retention time. HPLC-MS/MS can in principle provide a definitive identification, and measurement not just of 8-oxodGuo but also of other oxidative DNA lesions; but until now it has proved to be a demanding and complicated method and has not given reliable results in the analysis of 8-oxodGuo.

The enzymic approach, using FPG to convert oxidized purines to DNA breaks, appears to be relatively free from the problem of spurious oxidation. But to exploit this approach to full effect, we need to be able to use it quantitatively, and so we must address the question of which lesions FPG detects, and how efficiently. The calibration of the enzymic methods should not rely solely on comparison with the effects of ionizing radiation. It is worth pointing out that the use of repair endonucleases is not limited to FPG; endonuclease III can be used in a similar way to detect oxidized pyrimidines, providing another biomarker of oxidative damage.

Notwithstanding the remaining problems, note that we are talking now about variation between the two approaches of 6-12-fold in measuring similar samples (HeLa cells or lymphocytes), compared with the far wider range that confronted us at the start of ESCODD. We are able to provide a realistic estimate of the actual background level of damage in lymphocytes; it is likely to lie somewhere between 4.2 and 0.38 -oxodGuo per $10^{6}$ guanines (i.e., the median values of the means from different laboratories, for HPLC and the comet assay).

The implications of this conclusion are far-reaching. Many trials have been carried out in which human lymphocytes, or tissues from normal or tumor tissue, have been analyzed for 8-oxodGuo using the techniques that we have tested (or GC-MS, which was represented in previous rounds of ESCODD). One topic under intensive investigation that is affected by this measurement problem is that of dietary antioxidants. In numerous studies, volunteers have taken supplements of antioxidants such as vitamin $\mathrm{C}$, carotenoids, or flavonoids, or foods rich in antioxidants, and oxidized bases have been measured in the DNA of white blood cells. It is important to know whether these supplements are effective in decreasing the level of damage - which would support claims that they may help to prevent cancer. It will be necessary to reexamine those published reports that are based on claims of much higher values of 8-oxodGuo than 4 per $10^{6}$ guanines. In future, with the information that we have provided, a more rigorous approach can be followed.

\section{ACKNOWLEDGMENTS}

Laboratory 4 would like to thank Professor P. Fondu (Laboratory of Hematology and Clinical Chemistry, Brugmann University Hospital, Brussels, Belgium) for help with collection of blood samples. This work was supported by the European Commission (QLK1-1999-00568) and the Scottish Executive Environment and Rural Affairs Department.

\section{REFERENCES}

1. Collins, A., Cadet, J., Epe, B., and Gedik, C. (1997) Problems in the measurement of 8oxoguanine in human DNA. Report of a workshop, DNA Oxidation, held in Aberdeen, UK, 1921 January, 1997. Carcinogenesis 18, 1833-1836 
2. ESCODD (2002) Inter-laboratory validation of procedures for measuring 8-oxo7,8dihydroguanine/8-oxo-7,8-dihydro-2'-deoxyguanosine in DNA. Free Rad. Res. 36, 239-245

3. Riis, B., ESCODD (2002) Comparison of results from different laboratories in measuring 8oxo2'-deoxyguanosine in synthetic oligonucleotides. Free Rad. Res. 36, 649-659

4. ESCODD (2002) Comparative analysis of baseline 8-oxo-7,8-dihydroguanine in mammalian cell DNA, by different methods in different laboratories: an approach to consensus. Carcinogenesis 23, 2129-2133

5. ESCODD (2003) Measurement of DNA oxidation in human cells by chromatographic and enzymic methods. Free Rad. Biol. Med. 34, 1089-1099

6. Ravanat, J.-L-, Douki, T., Duez, P., Gremaud, E., Herbert, K., Hofer, T., Lasserre, L., SaintPierre, C., Favier, A., and Cadet, J. (2002) Cellular background level of 8-oxo-7,8-dihydro2'deoxyguanosine: an isotope based method to evaluate artefactual oxidation of DNA during its extraction and subsequent work-up. Carcinogenesis 23, 1911-1918

7. Collins, A. R., and Dušinská, M. (2002) Oxidation of cellular DNA measured with the comet assay. In Methods in Molecular Biology (Armstrong, D., ed) vol. 186, pp.147-159, Humana Press, Totowa, NJ

8. Epe, B., and Hegler, J. (1994) Oxidative DNA damage: endonuclease fingerprinting. Methods Enzymol. 234, 122-131

9. Pflaum, M., Will, O., and Epe, B. (1997) Determination of steady-state levels of oxidative DNA base modifications in mammalian cells by means of repair endonucleases. Carcinogenesis 18, 2225-2231

10. Hartwig, A., Dally, H., and Schlepegrell, R. (1996) Sensitive analysis of oxidative DNA damage in mammalian cells: Use of the bacterial Fpg protein in combination with alkaline unwinding. Toxicol. Lett. 88, 85-90

11. Merzenich, M., Hartwig, A., Ahrens, W., Beyersmann, D., Scholze, M., Timm, J., and Jöckel, K.-H. (2001) Biomonitoring on carcinogenic metals and oxidative DNA damage in a crosssectional study. Cancer Epidemiol. Biomark. Prev. 10, 515-522

12. Singh, R., McEwan, M., Lamb, J. H., Santella, R. M., and Farmer, P. B. (2003) An improved liquid chromatography/tandem mass spectrometry method for the determination of 8-oxo7,8dihydro-2-deoxyguanosine in DNA samples using immunoaffinity column purification. Rapid Commun. Mass Spectrom. 17, 126-134

13. Bland, J. M., and Altman, D. G. (1986) Statistical methods for assessing agreement between two methods of clinical measurement. Lancet i, 307-310

14. Gedik, C. M., Boyle, S. P., Wood, S. G., Vaughan, N. J., and Collins, A. R. (2002) Oxidative stress in humans: validation of biomarkers of DNA damage. Carcinogenesis 23, 1441-1446 
15. Pflaum, M., Will, O., and Epe, B. (1997) Determination of steady-state levels of oxidative DNA base modifications in mammalian cells by means of repair endonucleases. Carcinogenesis $\mathbf{1 8 ,}$ $2225-2231$

Received May 24, 2004; accepted September 22, 2004. 


\section{Table 1}

Variations in methods used for preparing DNA for analysis by HPLC. Laboratories that received samples but did not submit results are not listed here ${ }^{a}$

\begin{tabular}{|c|c|c|c|c|c|c|c|c|c|}
\hline 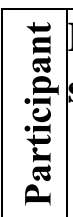 & $\begin{array}{l}\text { Purging of } \\
\text { solutions }\end{array}$ & $\begin{array}{l}\text { Antioxidant/ } \\
\text { chelator in } \\
\text { homogenizing } \\
\text { buffer }\end{array}$ & \begin{tabular}{|l|} 
Detergent \\
to lyse cells
\end{tabular} & $\begin{array}{l}\text { Antioxidant/ } \\
\text { chelator in nuclear } \\
\text { resuspension } \\
\text { buffer }\end{array}$ & $\begin{array}{l}\text { SDS treatment } \\
\text { (temp., time) }\end{array}$ & \begin{tabular}{|l} 
RNase \\
treatment \\
(temp., \\
time)
\end{tabular} & $\begin{array}{l}\text { Protein } \\
\text { digestion } \\
\text { (temp.,time) }\end{array}$ & $\begin{array}{l}\text { Chloroform/3methyl } \\
\text { 1butanol extraction }\end{array}$ & $\begin{array}{l}\text { Precipitation of } \\
\text { remaining } \\
\text { protein with } \\
\text { salt }\end{array}$ \\
\hline 2 & No & $5 \mathrm{mM} \mathrm{DF}$ & Triton X-100 & $05 \mathrm{mM} \mathrm{DF}$ & $\begin{array}{l}37^{\circ} \mathrm{C} \\
10 \mathrm{~min}\end{array}$ & $\begin{array}{l}37^{\circ} \mathrm{C} \\
30 \mathrm{~min}\end{array}$ & $\begin{array}{l}37^{\circ} \mathrm{C} \\
30 \mathrm{~min}\end{array}$ & Yes & Yes \\
\hline 3 & No & $0.1 \mathrm{mM}$ DF & Triton X-100 & $\begin{array}{l}95 \mathrm{mM} \text { EDTA, } \\
0.15 \mathrm{mM} \text { DF }\end{array}$ & $\mathrm{RT}, 5 \mathrm{~min}$ & $\begin{array}{l}50^{\circ} \mathrm{C} \\
15 \mathrm{~min}\end{array}$ & $\begin{array}{l}37^{\circ} \mathrm{C} \\
1 \mathrm{~h}\end{array}$ & No & No \\
\hline 4 & No & $0.1 \mathrm{mM}$ DF & Triton X-100 & $\begin{array}{l}95 \mathrm{mM} \text { EDTA, } \\
0.15 \mathrm{mM} \text { DF }\end{array}$ & $\mathrm{RT}, 5$ min & $\begin{array}{l}50^{\circ} \mathrm{C} \\
15 \mathrm{~min}\end{array}$ & $\begin{array}{l}37^{\circ} \mathrm{C} \\
1 \mathrm{~h}\end{array}$ & No & No \\
\hline 5 & $\mathrm{Ar}$ & $5 \mathrm{mM}$ DF & Triton X-100 & $05 \mathrm{mM}$ DF & $\begin{array}{l}37^{\circ} \mathrm{C} \\
10 \mathrm{~min}\end{array}$ & $\begin{array}{l}37^{\circ} \mathrm{C} \\
30 \mathrm{~min}\end{array}$ & $\begin{array}{l}37^{\circ} \mathrm{C} \\
30 \mathrm{~min}\end{array}$ & Yes & Yes \\
\hline 6 & $\mathrm{~N}_{2}$ & $5 \mathrm{mM}$ DF & Triton X-100 & $05 \mathrm{mM}$ DF & $\begin{array}{l}37^{\circ} \mathrm{C} \\
10 \mathrm{~min}\end{array}$ & $\begin{array}{l}37^{\circ} \mathrm{C} \\
30 \mathrm{~min}\end{array}$ & $\begin{array}{l}37^{\circ} \mathrm{C} \\
30 \mathrm{~min}\end{array}$ & Yes & Yes \\
\hline 9 & No & $1 \mathrm{mM}$ DF & Triton X-100 & $01 \mathrm{mM} \mathrm{DF}$ & $\begin{array}{l}37^{\circ} \mathrm{C} \\
10 \mathrm{~min}\end{array}$ & $\begin{array}{l}37^{\circ} \mathrm{C} \\
30 \mathrm{~min}\end{array}$ & $\begin{array}{l}37^{\circ} \mathrm{C} \\
30 \mathrm{~min}\end{array}$ & Yes & Yes \\
\hline 13 & No & $0.1 \mathrm{mM}$ DF & Triton X-100 & $0.1 \mathrm{mM} \mathrm{DF}$ & $\begin{array}{l}37^{\circ} \mathrm{C} \\
10 \mathrm{~min}\end{array}$ & $\begin{array}{l}37^{\circ} \mathrm{C} \\
1 \mathrm{~h}\end{array}$ & $\begin{array}{l}37^{\circ} \mathrm{C} \\
2 \mathrm{~h}\end{array}$ & No & No \\
\hline 14 & No & $0.1 \mathrm{mM}$ DF & Triton X-100 & $\begin{array}{l}55 \mathrm{mM} \text { EDTA, } \\
0.15 \mathrm{mM} \text { DF }\end{array}$ & $\begin{array}{l}37^{\circ} \mathrm{C} \\
15 \mathrm{~min}\end{array}$ & $\begin{array}{l}50^{\circ} \mathrm{C} \\
15 \mathrm{~min}\end{array}$ & $\begin{array}{l}37^{\circ} \mathrm{C} \\
1 \mathrm{~h}\end{array}$ & No & No \\
\hline 15 & $\begin{array}{l}\text { No: Chelex } \\
\text { used }\end{array}$ & $1 \mathrm{mM} \mathrm{DF}$ & Tween-20 & 4 M GTC & None & None & None & Yes & No \\
\hline 16 & No & $\begin{array}{l}1 \mathrm{mM} \text { DF, } 3 \\
\text { mM reduced } \\
\text { GSH, } 4 \mathrm{mM} \\
\text { his, } 1 \mathrm{mM} \text { DTT }\end{array}$ & Triton X-100 & $\begin{array}{l}1 \mathrm{mM} \text { DF, } 3 \mathrm{mM} \\
\text { reduced GSH, } 4 \\
\mathrm{mM} \text { his, } 1 \mathrm{mM} \text { DTT }\end{array}$ & $\begin{array}{l}37^{\circ} \mathrm{C} \\
30 \mathrm{~min}\end{array}$ & $\begin{array}{l}37^{\circ} \mathrm{C} \\
30 \mathrm{~min}\end{array}$ & $\begin{array}{l}37^{\circ} \mathrm{C}, \\
1 \mathrm{~h}\end{array}$ & Yes & No \\
\hline
\end{tabular}




\section{Table 1 (cont)}

\begin{tabular}{|c|c|c|c|c|c|c|c|c|c|}
\hline 21 & No & $1 \mathrm{mM}$ DF & No & $1 \mathrm{mM} \mathrm{DF}$ & $\begin{array}{l}50^{\circ} \mathrm{C}, \\
1 \mathrm{~h} \\
\end{array}$ & $\begin{array}{l}37^{\circ} \mathrm{C} \\
1 \mathrm{~h}\end{array}$ & None & No & No \\
\hline 23 & No & $0.1 \mathrm{mM}$ DF & Triton X-100 & $\begin{array}{l}5 \text { mM EDTA, } \\
0.15 \text { mM DF }\end{array}$ & $\mathrm{RT}, 5 \mathrm{~min}$ & $\begin{array}{l}50^{\circ} \mathrm{C} \\
15 \mathrm{~min}\end{array}$ & $\begin{array}{l}37^{\circ} \mathrm{C} \\
1 \mathrm{~h}\end{array}$ & No & No \\
\hline 25 & No & $0.1 \mathrm{mM}$ DF & No & $0.15 \mathrm{mM}$ DF & $\begin{array}{l}50^{\circ} \mathrm{C} \\
15 \mathrm{~min}\end{array}$ & $\begin{array}{l}50^{\circ} \mathrm{C}, \\
15 \mathrm{~min}\end{array}$ & $\begin{array}{l}37^{\circ} \mathrm{C} \\
1 \mathrm{~h}\end{array}$ & No & No \\
\hline 28 & No & $0.1 \mathrm{mM} \mathrm{DF}$ & Triton X-100 & $0.1 \mathrm{mM}$ DF & $\begin{array}{l}50^{\circ} \mathrm{C} \\
10 \mathrm{~min}\end{array}$ & $\begin{array}{l}50^{\circ} \mathrm{C}, \\
10 \mathrm{~min}\end{array}$ & $\begin{array}{l}37^{\circ} \mathrm{C}, \\
1 \mathrm{~h}\end{array}$ & No & No \\
\hline
\end{tabular}

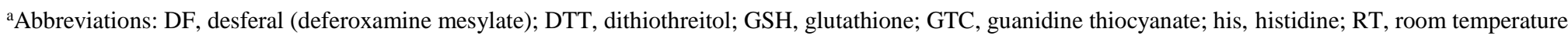


Page 14 of 23 (page number not for

$$
\text { citation purposes) }
$$


Variations in methods used for preparing DNA for analysis by HPLC (continued). Hydrolysis was with P1 nuclease/alkaline phosphatase in all cases. Electrochemical detection (coulometric) was used except where indicated (last column). Laboratories that received samples but did not submit results are not listed here ${ }^{a}$

\begin{tabular}{|c|c|c|c|c|c|c|}
\hline 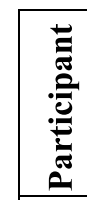 & $\begin{array}{l}\text { DNA } \\
\text { precipitated } \\
\text { with }\end{array}$ & Salt added & $\begin{array}{l}\text { Removal of excess } \\
\text { alcohol }\end{array}$ & $\begin{array}{l}\text { Method for dissolving } \\
\text { DNA }\end{array}$ & $\begin{array}{l}\text { Treatment of } \\
\text { hydrolysate }\end{array}$ & $\begin{array}{l}\text { Variation } \\
\text { of HPLC } \\
\text { detection }\end{array}$ \\
\hline 2 & Ethanol & None & $\begin{array}{l}\text { Pipette, stream of } \\
\mathrm{Ar}\end{array}$ & $\begin{array}{l}\text { Tris buffer, } 2 \mathrm{~h} \text { at } 37^{\circ} \mathrm{C}, \\
\text { overnight at } 4^{\circ} \mathrm{C}\end{array}$ & $\begin{array}{l}\text { Filtration } \\
\text { (Millipore } \\
\text { Micropure-EZ; } \\
\text { Enzyme Removers) } \\
\end{array}$ & \\
\hline 3 & 2-Propanol & $\mathrm{NaI}$ & Left in air, $10 \mathrm{~min}$ & $\begin{array}{l}0.1 \mathrm{mM} \mathrm{DF},<5 \mathrm{~min} \text { at } \mathrm{RT} \text {, } \\
\text { pipetting }\end{array}$ & & $\begin{array}{l}\text { MS/MS in } \\
\text { addition to } \\
\text { ECD }\end{array}$ \\
\hline 4 & 2-Propanol & $\mathrm{NaI}$ & Left in air, 5 min & $\begin{array}{l}0.1 \mathrm{mM} \mathrm{DF},<5 \mathrm{~min} \text { at } \mathrm{RT} \text {, } \\
\text { pipetting }\end{array}$ & None & $\begin{array}{l}\text { Ampero- } \\
\text { metric }\end{array}$ \\
\hline 5 & Ethanol & $\mathrm{NaCl}$ & Stream of Ar & $\begin{array}{l}\text { Tris buffer, overnight at } \\
4^{\circ} \mathrm{C}, 2 \mathrm{~h} \text { at } 37^{\circ} \mathrm{C}\end{array}$ & None & \\
\hline 6 & Ethanol & $\mathrm{NaCl}$ & Pipette & $\begin{array}{l}\text { Tris buffer, overnight at } \\
4^{\circ} \mathrm{C}\end{array}$ & None & \\
\hline 9 & Ethanol & None & Stream of $\mathrm{N}_{2}$ & $\begin{array}{l}\text { Tris buffer, overnight at } \\
4^{\circ} \mathrm{C}, 2 \mathrm{~h} \text { at } 37^{\circ} \mathrm{C}\end{array}$ & None & $\begin{array}{l}\text { Ampero- } \\
\text { metric }\end{array}$ \\
\hline 13 & Ethanol & None & Left in air, $5 \mathrm{~min}$ & $0.1 \mathrm{mM}$ DF & $\begin{array}{l}\text { Filtration }(30 \mathrm{kDa} \\
\text { cut-off) }\end{array}$ & \\
\hline 14 & 2-Propanol & $\mathrm{NaI}$ & \begin{tabular}{|l|} 
Pipette, then \\
transfer to dry tube
\end{tabular} & Water, vigorous agitation & $\begin{array}{l}\text { Chloroform } \\
\text { extraction }\end{array}$ & \\
\hline 15 & 2-Propanol & None & Pipette & $\begin{array}{l}\text { Water with } \\
\text { TEMPO/catalase; pipette } \\
\text { on ice } 5 \text { min }\end{array}$ & $\begin{array}{l}\text { Chloroform } \\
\text { extraction }\end{array}$ & \\
\hline 16 & Ethanol & None & Stream of $\mathrm{N}_{2}$ & $\begin{array}{l}\text { Acetate buffer with } \mathrm{ZnCl}_{2} \text {, } \\
\text { agitate } 5 \mathrm{~min} \text { at RT }\end{array}$ & $\begin{array}{l}\text { Filtration }(5 \mathrm{kDa} \\
\text { cut-off) }\end{array}$ & \\
\hline 21 & 2-Propanol & $\mathrm{NaI}$ & Stream of $\mathrm{He}$ & $\begin{array}{l}\text { Tris/EDTA buffer, } 30 \mathrm{~min} \\
\text { at RT }\end{array}$ & None & \\
\hline 23 & 2-Propanol & $\mathrm{NaI}$ & Left in air, $5 \mathrm{~min}$ & $\begin{array}{l}0.1 \mathrm{mM} \mathrm{DF},<5 \mathrm{~min} \text { at } \mathrm{RT} \text {, } \\
\text { pipetting }\end{array}$ & None & \\
\hline 25 & $\begin{array}{l}\text { 2-Propanol + } \\
\text { ethanol }\end{array}$ & $\mathrm{NaI}$ & Stream of $\mathrm{N}_{2}$ & $0.1 \mathrm{mM} \mathrm{DF}, 5 \mathrm{~min}$ at $\mathrm{RT}$ & $\begin{array}{l}\text { Filtration (10 kDa } \\
\text { cut-off) }\end{array}$ & \\
\hline 28 & 2-Propanol & $\mathrm{NaI}$ & Left in air & $\begin{array}{l}\text { Tris buffer, } 0.1 \mathrm{mM} \mathrm{DF} \text {, } \\
10 \text { min at RT }\end{array}$ & $\begin{array}{l}\text { Filtration } \\
\text { (Millipore } \\
\text { Micropure-EZ; } \\
\text { Enzyme Removers) }\end{array}$ & \\
\hline
\end{tabular}

${ }^{a}$ Abbreviations: RT, room temperature; DF, desferal (deferoxamine mesylate); TEMPO, 2,2,6,6-tetramethylpiperidine- $N$-oxyl. 
Table 3

CVs (\%) of determination of 8-oxodGuo in HeLa cells and lymphocytes by HPLC (with laboratories' own extraction methods) ${ }^{a}$

HeLa cells

Participant

\section{HeLa cells} Intertube Intra-tube

\begin{tabular}{l}
\hline 2 \\
3 \\
3 \\
4 \\
5 \\
6
\end{tabular}

2
3

3

4

5

6

9 (amperometric)

27

(MS/MS)

(amperometric)

43

9

7

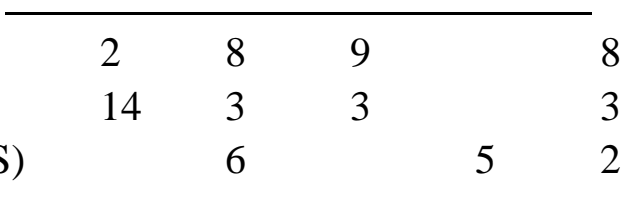

Median

Lymphocytes

26

22

Intra-tube Median Range

$1425438452-17155155221922 \quad 122-36$

16

6

4-120

21 (own method) 8191121

25

24

6

$19 \quad 10$

$\begin{array}{lll}3 & 4 & 4\end{array}$

10

4

5

\section{8}

3

5

4

3

4

$6 \quad 1-13$

$15 \quad 1-43$

$\begin{array}{ll}6 & 5\end{array}$

28

$\begin{array}{rr}7 & 14 \\ & \end{array}$

$1825 \quad 25 \quad 94-24$

5 


\section{Table 4}

Correlations between individual values for concentrations of 8-oxodGuo (HPLC) and FPG-sites (comet assay) in those laboratories performing both assays

\begin{tabular}{|l|l|l|l|}
\hline Participant & $\begin{array}{l}\text { Number of } \\
\text { volunteers }\end{array}$ & Correlation (r) & $\mathbf{P}$ \\
\hline 2 & 16 & -0.30 & $\mathrm{NS}^{a}$ \\
\hline 4 & 11 & 0.59 & $\mathrm{NS}$ \\
\hline 5 & 17 & -0.14 & $\mathrm{NS}$ \\
\hline 6 & 20 & 0.93 & $<0.001$ \\
\hline 14 & 8 & -0.11 & $\mathrm{NS}$ \\
\hline 15 & 16 & -0.41 & $\mathrm{NS}$ \\
\hline
\end{tabular}

${ }^{a} \mathrm{NS}$; not significant 
Fig. 1
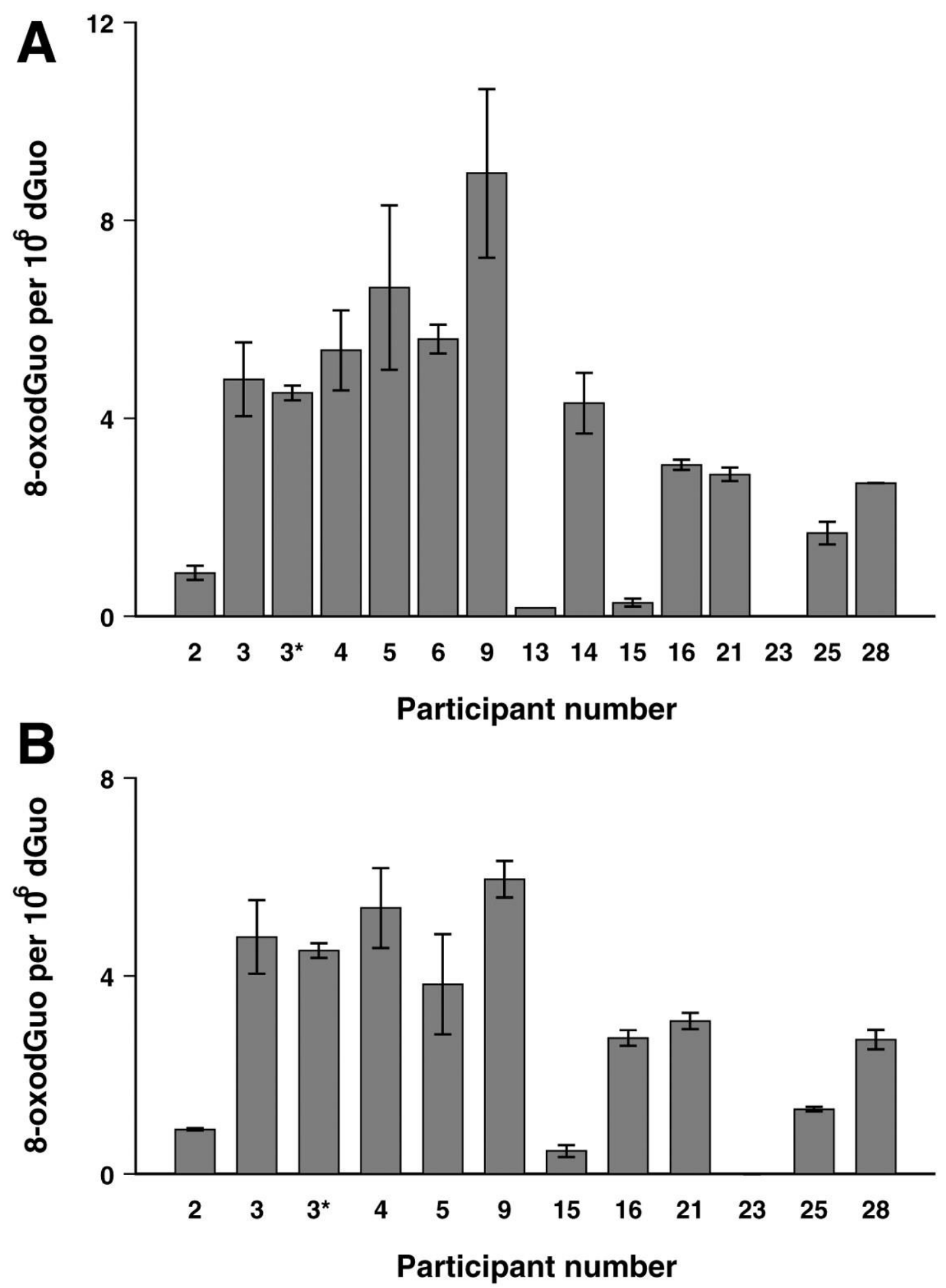

Figure 1. Concentrations of 8-oxodGuo in standard samples of HeLa cells, as measured by HPLC. $A$ ) Using laboratories' own methods. B) using ESCODD standard method. The "own method" of laboratories 3, 4, and 23 was the ESCODD method, and the same results appear on both graphs. Laboratories 6 and 13 used only their own protocol. Laboratory 3 used HPLC-MS/MS (3*) in addition to HPLC-ECD (3). Peaks were not detected by laboratory 23. Laboratory 13 detected a peak in only one sample. Bars indicate SE. 
Fig. 2

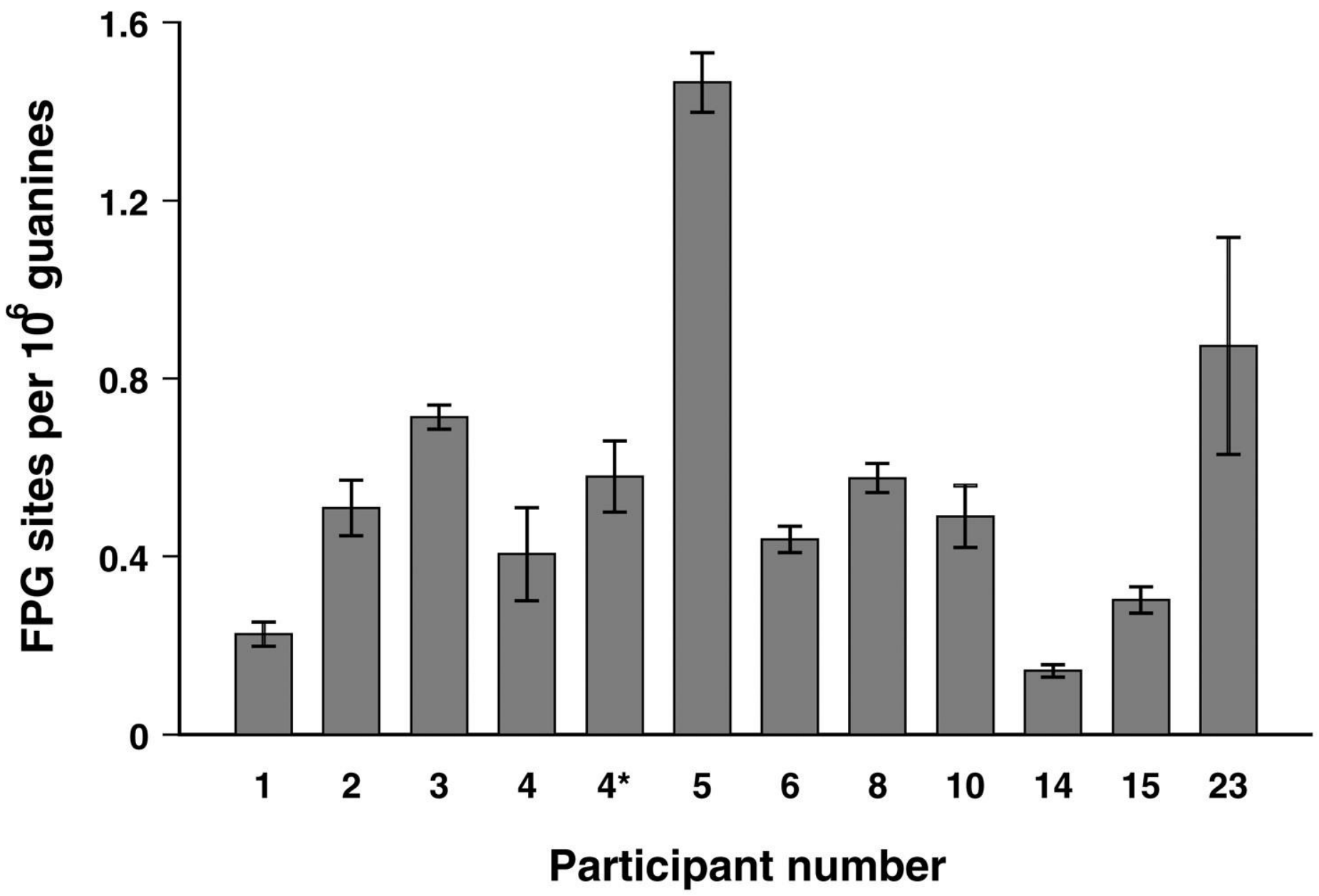

Figure 2. Frequencies of FPG-sensitive sites in standard samples of HeLa cells, as measured by enzymic methods. Laboratory 8 used alkaline elution; laboratories 10 and 23 used alkaline unwinding; all others used the comet assay. Laboratory 4 carried out electrophoresis at $18^{\circ} \mathrm{C}\left(4^{*}\right)$ as well as at the standard temperature of $4^{\circ} \mathrm{C}$

(4). Bars indicate SE. 
Fig. 3

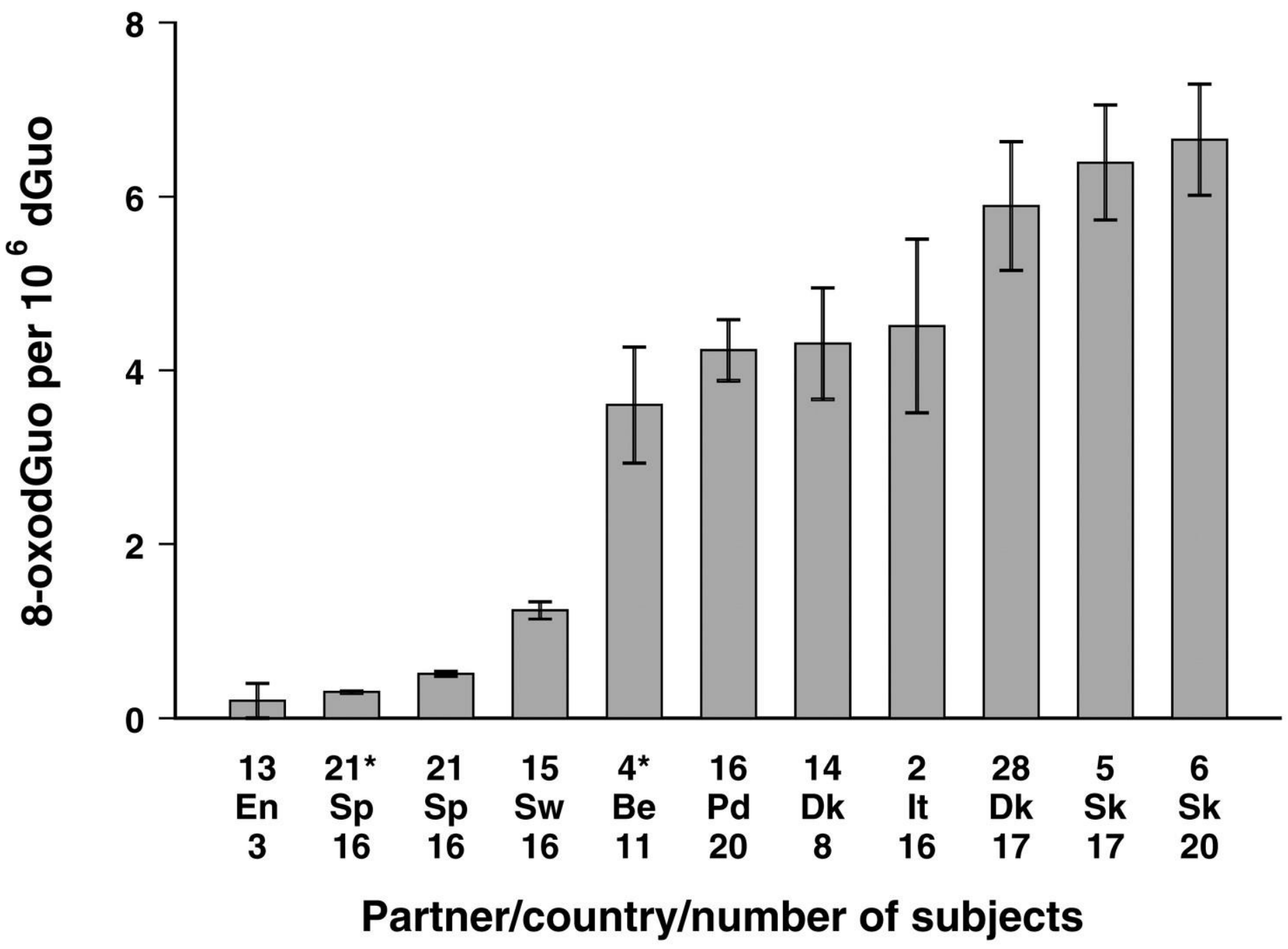

Figure 3. Mean concentrations of 8-oxodGuo (measured by HPLC) in lymphocytes from volunteers in different countries. Bars indicate SE. Below horizontal axis: first line, partner number; second line, country; third line, number of subjects. Abbreviations: En, England; Sp, Spain; Sw, Sweden; Be, Belgium; Pd, Poland; Dk, Denmark; It, Italy; Sk, Slovakia. *Standard ESCODD protocol used to extract/hydrolyse DNA; otherwise, individual laboratory procedures were used. Two of the three samples analyzed by laboratory 13 did not give detectable peaks; they were entered as 0 in calculating the mean. 
Fig. 4

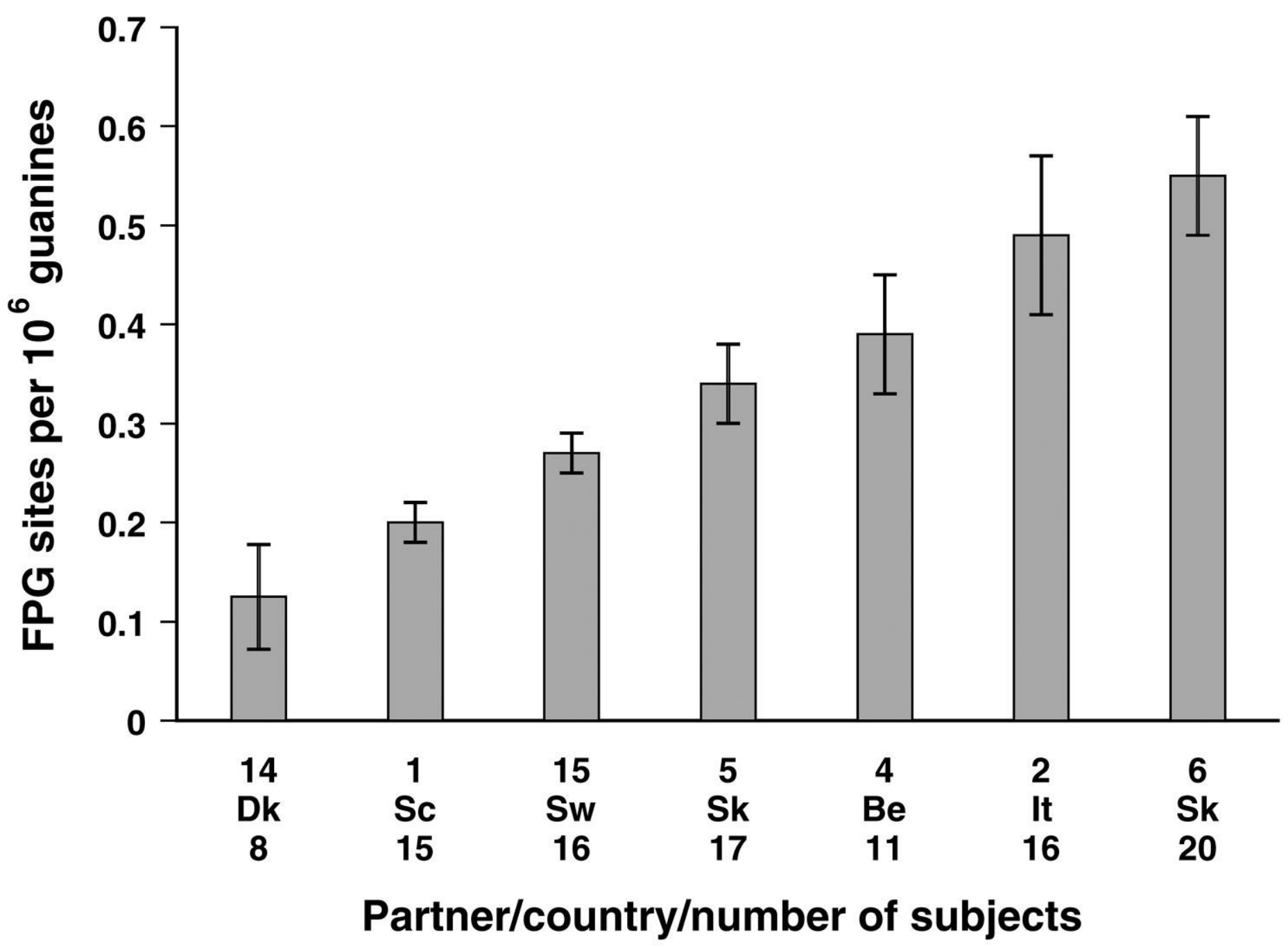

Figure 4. Mean frequencies of FPG-sensitive sites (measured with the comet assay) in lymphocytes from volunteers in different countries. Bars indicate SE. Below horizontal axis: first line, partner number; second line, country; third line, number of subjects. Abbreviations: Dk, Denmark; Sc, Scotland; Sw, Sweden; Sk, Slovakia; Be, Belgium; It, Italy. 
Fig. 5

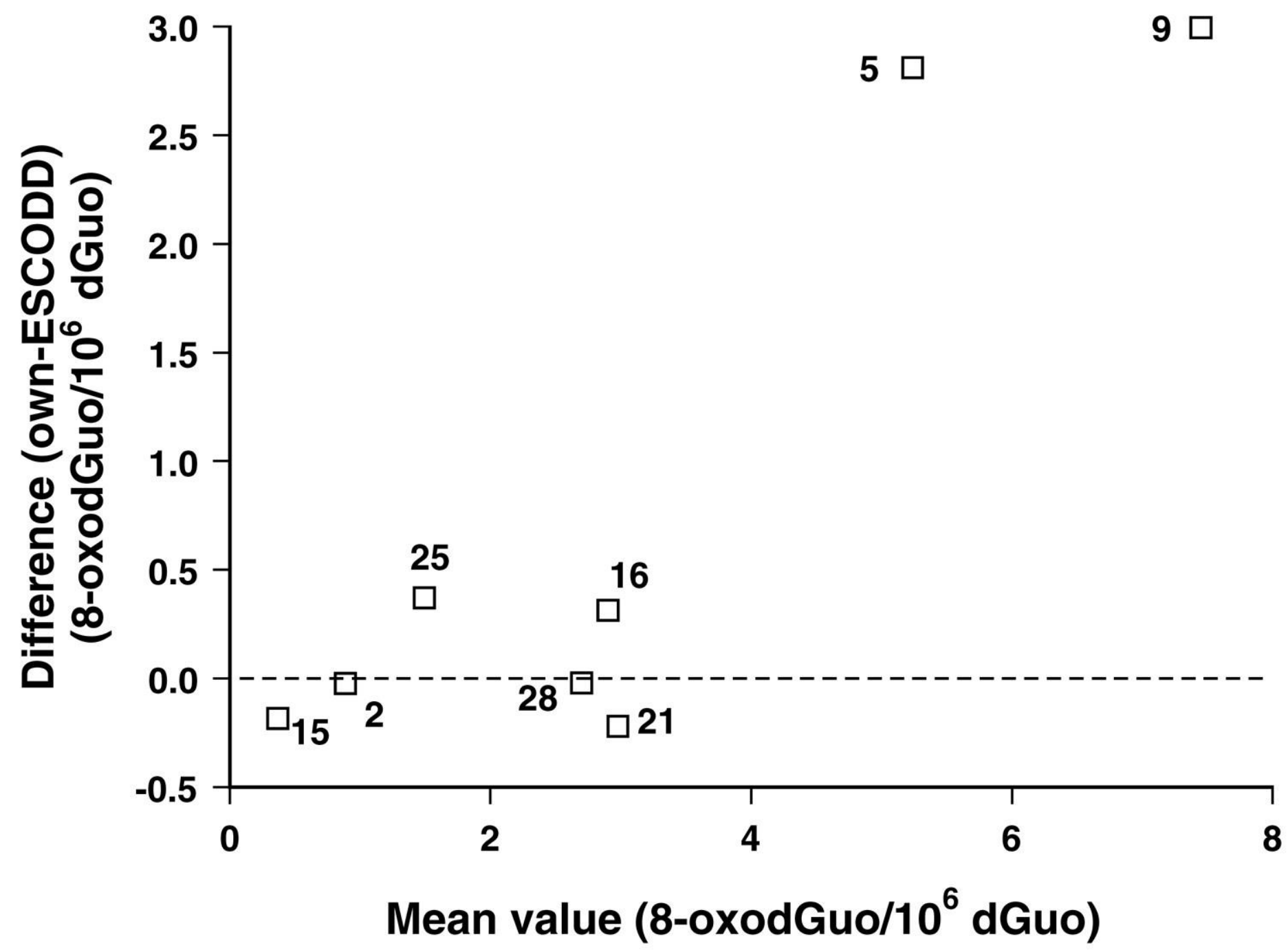

Figure 5. Bland and Altman plot of results from laboratories comparing their own with the ESCODD method for DNA isolation and hydrolysis from HeLa cells. The difference between the (mean) values of 8-oxodGuo per $10^{6} \mathrm{dGuo}$ with the two procedures is plotted against the mean of these two values. 
Fig. 6

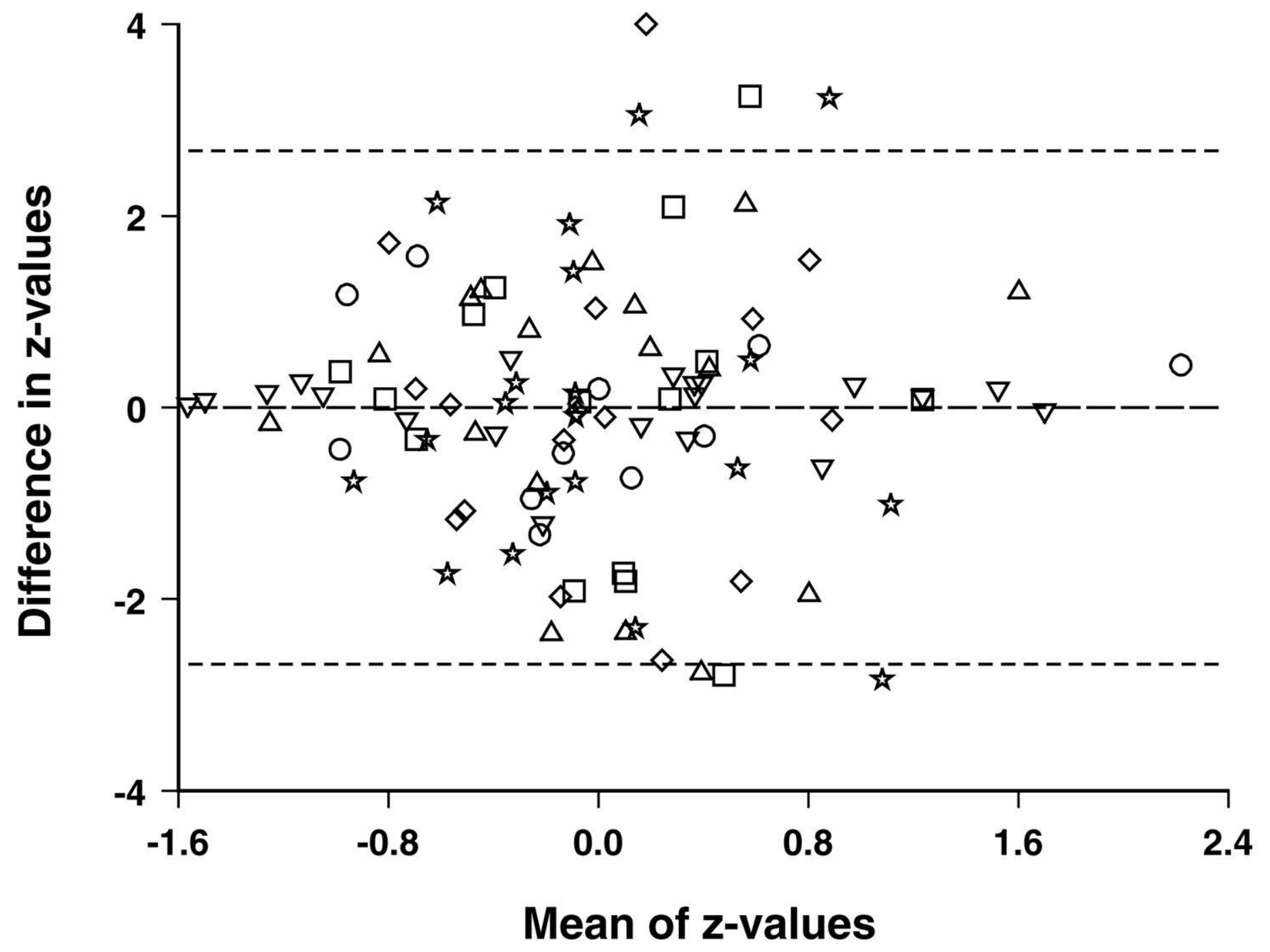

Figure 6. Individual results (8-oxodGuo or FPG-sensitive sites per $10^{6}$ guanines) from lymphocyte samples measured by both HPLC and the comet assay. Data from each laboratory were z-transformed (using the mean and SD for the set of data in that laboratory), and the difference in $z$-values (HPLC value minus comet assay value) for each individual is plotted here against the mean of the two $z$-values. The dashed lines represent the line of agreement $(y=-0.002$, long dashes) and $\pm 2 \times$ SD of all differences in $z$-values (short dashes). Laboratories represented: 2 (squares), 4 (circles), 5 (triangles), 6 (inverted triangles), 14 (stars), 15 (diamonds). 